Hidden 
This page intentionally left blank 


\section{Hidden Reflections on Gay Life, AIDS, and Spiritual Desire}

\section{Richard Giannone}

Fordham University Press | New York 2012 
All rights reserved. No part of this publication may be reproduced, stored in a retrieval system, or transmitted in any form or by any means-electronic, mechanical, photocopy, recording, or any other-except for brief quotations in printed reviews, without the prior permission of the publisher.

Fordham University Press has no responsibility for the persistence or accuracy of URLs for external or third-party Internet websites referred to in this publication and does not guarantee that any content on such websites is, or will remain, accurate or appropriate.

Fordham University Press also publishes its books in a variety of electronic formats. Some content that appears in print may not be available in electronic books.

Library of Congress Cataloging-in-Publication Data

Giannone, Richard.

Hidden : reflections on gay life, AIDS, and spiritual desire / Richard Giannone.-1st ed.

p. $\mathrm{cm}$.

ISBN 978-o-8232-4184-2 (cloth : alk. paper)

1. Giannone, Richard. 2. Catholic gay men-New York-New York-Biography.

3. Care of the sick. 4. Caring-Religious aspects-Catholic Church. I. Title.

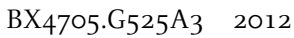

$282.092-\mathrm{dc} 23$

[B]

2011047353

Printed in the United States of America

$\begin{array}{llllllll}14 & 13 & 12 & 5 & 4 & 3 & 2 & 1\end{array}$

First edition 
In memory of

Nellie Cordileone Giannone and Marie Rose Giannone and for Frank 
This page intentionally left blank 